\title{
Gambaran Sosial Masyarakat Minangkabau dalam Menghadapi Perkembangan Zaman di Novel Anak Rantau Karya Ahmad Fuadi
}

\author{
Emiliana Endang Ismijatie \\ Universitas Indraprasta PGRI \\ Jalan Nangka No. 58 C/TB. Simatupang, Tanjung Barat, Jakarta Selatan 12530 \\ emilismijati@yahoo.co.id
}

\begin{abstract}
The purpose of this research is to find out the social group interaction of Minangkabau Society, ideological transformation and values in dealing with the era development. This research uses the design of analisys research on the phenomenon depicted at Anak Rantau novel written by Ahmad Fuadi. This research proves that there are three social groups found in Minangkabau Society which interacts with each others and the three groups meet the ideological transformation and values in Minangkabau society.
\end{abstract}

Keywords: Social interaction, ideology, values

\begin{abstract}
Abstrak
Penelitian ini bertujuan mengetahui interaksi kelompok sosial Masyarakat Minangkabau dan perubahan ideologi dan nilai-nilai dalam menghadapi perkembangan zaman. Penelitian menggunakan desain penelitian analisis pada fenomena yang digambarkan pada Novel Anak Rantau karya Ahmad Fuadi. Hasil penelitian membuktikan bahwa ada tiga kelompok sosial yang terdapat dalam Masyarakat Minangkabau yang saling berinteraksi dan ketiga kelompok itu mengalami perubahan ideologi dan nilai-nilai dalam masyarakat Minangkabau.
\end{abstract}

Kata Kunci: Interaksi sosial, ideologi, nilai-nilai

\section{PENDAHULUAN}

Karya sastra diciptakan oleh sastrawan untuk dinikmati, dipahami, dan dimanfaatkan oleh masyarakat. Sastrawan itu sendiri adalah anggota masyarakat; ia terikat oleh status sosial tertentu. Sastra adalah lembaga sosial yang menggunakan bahasa sebagai medium; bahasa itu sendiri merupakan ciptaan sosial. Sastra menampilkan gambaran kehidupan; dan kehidupan itu sendiri adalah suatu kenyataan sosial. Dalam pengertian itu, kehidupan mencakup hubungan antarmasyarakat, antara anggota masyarakat, antarmanusia, dan antarperistiwa yang terjadi dalam batin seseorang. Bagaimanapun juga, peristiwa-peristiwa yang terjadi dalam batin seseorang, yang sering menjadi bahan sastra, adalah pantulan hubungan seseorang dengan orang lain atau dengan masyarakat. Hal itu menunjukkan bahwa sastra tidak jatuh begitu saja dari langit, bahwa hubungan yang ada antara sastrawan, sastra, dan masyarakat bukanlah sesuatu yang dicari-cari (Damono, 1978:1). 
Karya sastra adalah produk pengarang yang hidup di lingkungan sosial. Dengan begitu, karya sastra merupakan dunia imajinatif pengarang yang selalu terkait dengan kehidupan sosial. Pengarang sebagai anggota masyarakat, dilahirkan, dibesarkan dan memeroleh pendidikan di tengah-tengah kehidupan sosial. Oleh karena itu, ia juga secara sadar atau tidak, telah menjalankan peranannya sebagai anggota masyarakat sejak lahir.

Junus (1986:3) mengemukakan bahwa karya sastra bisa dilihat sebagai dokumen sosial budaya yang mencatat kenyataan sosio-budaya suatu masyarakat pada suatu masa tertentu. Pendekatan tersebut bertolak dari anggapan bahwa karya sastra tidak lahir dari kekosongan budaya. Bagaimana pun karya sastra itu mencerminkan masyarakatnya dan secara tidak terhindarkan dipersiapkan oleh keadaan masyarakat dan kekuatan-kekuatan (ciri-ciri) pada zamannya.

Budaya dan sastra memiliki ketergantungan satu sama lain. Sastra sangat dipengaruhi oleh budaya sehingga segala hal yang terdapat dalam kebudayaan akan tercermin di dalam sastra. Jika kebudayaan adalah sistem yang mengatur interaksi manusia di dalam masyarakat, sastra adalah suatu sistem yang berfungsi sebagai sarana berlangsungnya interaksi. Sebagai contoh, kesusasteraan Indonesia menjadi potret sosial budaya masyarakat Indonesia. Tidak jarang, kesusasteraan Indonesia mencerminkan perjalanan sejarah Indonesia, kegelisahan kultural dan manifestasi pemikiran bangsa Indonesia (Teng, 2017: 72-73).

Pengarang, lewat karyanya, mencoba mengungkapkan fenomena kehidupan manusia yakni berbagai peristiwa dalam kehidupan ini. Karena karya sastra berisi catatan, rekaman, rekaan, dan ramalan kehidupan manusia, pada gilirannya, karya sastra sedikit banyak, acap kali mengandung fakta-fakta sosial. Bahkan karya sastra dapat mencerminkan perkembangan sosiologis atau menunjukkan perubahanperubahan watak kultural suatu masyarakat..

Dalam kaitan dengan hal tersebut, novel, sebagian besar, paling mendekati gambaran kehidupan sosial di dunia nyata dibandingkan puisi atau drama. Konflik yang dapat kita tangkap dalam novel adalah gambaran ketegangan antara individu dengan individu, lingkungan sosial, alam, dan Tuhan. Atau ketegangan individu dengan dirinya sendiri. Ketegangan-ketegangan itu sering kali justru dipandang sebagai cermin kehidupan masyarakat, yang di dalamnya terkandung juga akar budaya dan semangat zamannya. Karya sastra menjadi semacam dunia alternatif sebagai hasil reaksi-evaluatif yang dapat menjadi rekaman atau catatan. Dalam hal ini, sastrawan dapat saja bertindak sebagai "pencatat" dan "pengamat" peristiwaperistiwa; atau sebagai "peramal" yang mengungkapkan peristiwa yang bakal terjadi di masa mendatang sebagai reaksi dari peristiwa yang dicatat dan diamatinya. Benar-tidak ramalannya, bukan persoalan.

Dibandingkan dengan karya sastra dalam khazanah kesusasteraan negara lain, sastra Indonesia, khususnya novel, sesungguhnya lahir dan berkembang dalam dinamika sosial dan kultural yang khas. Khas lantaran mengejawantahkan heterogenitas manusia Indonesia berikut kebudayaannya yang begitu beragam. Novel Indonesia laksana merepresentasikan ruh, bahkan juga semangat kultural lingkungan sosial budaya etnisitas keindonesiaan yang di dalamnya akan termasuk juga ideologi orang per orang dalam lingkup komunitas etnik.

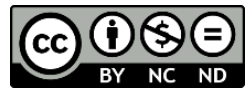


Istilah ideologi berasal dari kata 'idea' yang berarti gagasan, konsep, pengertian dasar, cita-cita dan kata "logos" yang dalam bahasa Yunani logos artinya ilmu atau pengetahuan. Secara harfiah ideologi diartikan sebagai seperangkat keyakinan yang menjadi landasan bagi orang, masyarakat atau negara untuk melaksanakan suatu tindakan.

Setiap ideologi terikat pada budaya. Siapa pun yang memelajari suatu budaya, maka ia berurusan dengan ideologi. Dan siapa pun yang memelajari ideologi, maka ia harus memerhatikan budayanya. Ideologi yang menentukan visi dan pandangan suatu kelompok budaya terhadap kenyataan. Dengan mengenali ideologinya, kita akan memahami suatu kelompok budaya secara lebih baik.

Nilai, yang dalam bahasa Inggris disebut value, berarti harga atau penghargaan yang melekat pada sebuah objek. Artinya, harga atau penghargaan yang melekat pada sebuah objek. Objek yang dimaksud bisa berbentuk benda, barang, keadaan, perbuatan, atau perilaku. Dalam teks sastra, nilai adalah semua kriteria dan penilaian moral atau politik yang digambarkan dalam teks atau ditampilkan secara eksplisit maupun implisit.

Nilai adalah sesuatu yang abstrak, bukan konkret. Nilai hanya bisa dipikirkan, dipahami, dan dihayati. Nilai juga berkaitan dengan cita-cita, harapan, keyakinan, dan hal-hal yang bersifat batiniah.

Kusumohamidjojo dalam Wellek dan Warren ( 1990). mengatakan bahwa nilai (value) adalah apa yang dianggap baik, apa yang dihargai tinggi, apa yang diinginkan, apa yang dicita-citakan, atau apa yang dikejar dalam hidup manusia baik sebagai individu maupun sebagai masyarakat. Nilai adalah sesuatu yang menarik, sesuatu yang menyenangkan, sesuatu yang berharga, sesuatu yang bermanfaat, atau sesuatu yang diminati. Tujuan hidup yang ingin dicapai seperti kesuksesan, kebahagiaan, kehormatan, tanggung jawab, kejujuran, iman, dan sebagainya merupakan bagian dari nilai. Nilai mencakup juga prinsip-prinsip hidup seperti bertindak adil, membantu orang yang membutuhkan, dan sebagainya. Oleh sebab itu, nilai tidak bisa dipisahkan dari proses pemaknaan (pemberartian) oleh individu dan masyarakat. Nilai bercirikan personal (subjektif) dan sosial sekaligus karena proses pemaknaan tersebut melibatkan masyarakat.

Sebelum masuknya Agama Islam ke Nusantara, bahkan sebelum masuknya agama Hindu di abad ke-1 Masehi, nenek moyang orang Minangkabau sudah menyusun aturan atau norma kehidupan bermasyarakat dalam bentuk adat Minangkabau, berdasarkan ketentuan-ketentuan alam yang nyata. Mereka menganut ideologi "Alam takambang jadi guru" dengan empat tolok ukur: Raso, Pareso, Alua dan Patuik. Ideologi itu, sampai datangnya Agama Islam ke ranah Minang, diwariskan dari satu generasi ke generasi berikutnya sampai sekarang. Dalam fatwa adat ditemukan pepatah yang berbunyi :

Panakiak pisausirauik, ambiak galah batang lintabuang, salodang jadikan niru. Nan satitiak jadikan lauik, nan sakapa jadikan gunuang, alam takambang jadikan guru

Artinya, air yang setitik rela (ihklas) diterima laksana sebanyak air lautan, tanah yang sekepal (segenggam tangan) rela diterima laksana sebesar gunung dan alam semesta raya ini dijadikan guru (tempat belajar dan atau pemberi pelajaran).

Rumah gadang bari bapintu, nak tarang sampai kadalam 


\section{Diskursus: Jurnal Pendidikan Bahasa Indonesia}

Vol. 2, No. 2, Agustus 2019, pp. 152-159

p-ISSN: 2615-4935

e-ISSN: 2615-4943

Kalau dibalun sagadang kuku, kalau dikambang saleba alam

Walau sagadang biji labu, bumi jo langik ado di dalam

Artinya, ajaran adat Minangkabau akan dapat dimanfaatkan untuk mengatur masyarakat, semenjak dari yang kecil seperti keluarga, sampai kepada yang lebih besar seperti negara dan dunia.

Dari fatwa adat di atas kita dapat menarik kesimpulan bahwa adat Minangkabau itu jujur sebagaimana jujurnya alam, nyata dan transparan sebagaimana nyatanya alam itu pula, tidak rumit, tidak sulit dan tidak mungkin pula dipersulit dalam mengamalkannya, dan segala sesuatu yang dibutuhkan manusia ada di dalamnya.

Bagaimanapun kecilnya di dalam fatwa itu terkandung nilai yang tinggi dan luhur, ibarat setetes air bermuatan sebesar lautan, ibarat sekepal tanah bermuatan sebesar gunung yang menjulang ke angkasa, ibarat sepotong salodang pinang yang jatuh ke tanah dapat dimanfaatkan sebagai niru pada zamannya. Walau hanya selebar kuku, adat dapat berfungsi sebagaimana lebarnya alam, walau hanya sebesar biji labu adat mengandung segala isi bumi dan langit, itulah adat Minangkabau

Ada tiga corak dan derajat ideologi; yang tertinggi ideologi atau pandangan hidup yang berdasarkan wahyu Tuhan, sebagaimana terdapat di dalam kitab suci yang disampaikan oleh para Rasul-Nya, yang kedua adalah pandangan hidup berdasarkan ketentuan yang terdapat dalam alam yang nyata ini, dan yang terendah atau ketiga adalah pandangan hidup yang timbul dari otak dan pikiran seorang filsuf. Sebelum masuknya agama Islam ke Minangkabau, ideologi yang dianut oleh nenek moyang orang Minangkabau waktu itu baru pada derajat kedua.

Dalam memahami dan menghayati ideologi adat Minangkabau itu setidaknya ada tiga nilai utama yang patut dikemukakan (1) Keyakinan akan kekuaasaan dan keesaan Allah Swt., berdasarkan syariat Islam. Orang Minangkabau yakin bahwa segala sesuatu yang terjadi di muka bumi ini atas kehendak dan kekuasaan Allah. Oleh sebab itu, semua hal yang berbau mistik, mempersekutukan Tuhan atau menyembah selain Allah, dihindari dan tidak ada di dalam adat Minangkabau. (2) Dalam fatwa adat ditemukan: Syarak mangato, Adat mamakai, apa yang diwajibkan oleh Agama Islam itu dipakai dan dilaksanakan dalam adat Minangkabau, dan apa yang diharamkan oleh Agama Islam dihindari dan dicegah oleh adat Minangkabau. Misalnya dalam upacara pelantikan seorang Pengulu, tidak ada acara memandikan keris walaupun keris lambang utama kepemimpinan seorang pengulu, tidak ada meletakkan sesajen di tempat-tempat keramat, dsb. (3) Persatuan dan kesatuan, sertakebersamaan dalam segala gerak kehidupan masyarakat. Apa saja yang dilakukan untuk kepentingan bersama atau orang banyak diadatkan di Minangkabau, harus melalui musyawarah, harus ada kesepakatan, harus ada tanggung jawab bersama, harus ada keadilan. (4) Keharmonisan berdasarkan keseimbangan, keserasian, keselarasan dan kemanusiaan. Bahwa ideologi adat Minangkabau itu mengajarkan warganya untuk hidup saling menghormati, tenggang rasa. Budi yang luhur merupakan nilai dasar dalam masyarakat Minangkabau, dan selalu didoktrinkan dengan berbagai cara, seperti pantun-pantun, pepatah-petitih, atau nyanyian klasik rakyat.

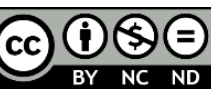

Creative Commons Attribution-NonCommercial-NoDerivatives 4.0 International License 
Minangkabau berkembang di surau, karena sisi religiusitas masyarakat Minangkabau tidak dapat kita pisahkan dari kesehariannya. Surau atau musalla/mesjid ini lazimnya, hanya digunakan untuk tempat beribadah, tapi di masyarakat Minangkabau surau memiliki peran yang cukup banyak seperti belajar mengenal agama, akhlak, pantun, randai dan adat budaya Minangkabau lainnya. Bahkan, di surau jugalah tempat pembinaan pribadi penerus generasi Minang yang siap menanggung beban dan amanah di kemudian.

Surau menjadi pranata penting dalam masyarakat Minangkabau, telah memainkan peranannya untuk memenuhi berbagai keperluan masayarakat dalam kehidupan sosial bermasyarakat. Tidak mengherankan kalau dulunya masyarakat Minangkabau banyak melahirkan tokoh-tokoh nasional yang berkiprah sampai tingkat internasional, itu semua disebabkan oleh peran surau yang sangat strategis dengan terbentuknya kepribadian yang tangguh dalam diri masyarakat Minangkabau

Budaya, adat, dan logat yang kental membuat di mana pun orang Minang berada, pasti akan terlihat jelas cirinya. Karena merantau bagi orang Minang adalah suatu kewajiban, mereka ada di banyak kota di Indonesia.

Sayangnya, seiring perjalanan waktu, terlebih dengan teknologi komunikasi dan transportasi yang mengalami revolusi pesat di era 1980-an, masyarakat Minang juga terkena dampaknya. Drastisnya perubahan kultural akibat masuknya ideologi asing menyebabkan budaya, adat, ideologi, nilai-nilai luhur Minangkabau mulai ditinggalkan dan dilupakan oleh anak muda Minang sekarang. Indak tau di nan ampek, alah hilang Minang tingga kabau. Norma, adat dan budaya yang sejak dulu menjadi kebanggaan orang Minang telah mulai pudar, hilang dan dilupakan oleh anak muda sekarang

Berdasarkan latar belakang seperti dikemukakan di atas, penelitian ini bertujuan mengetahui gambaran sosial masyarakat Minangkabau (interaksi antara kelompok sosial, ideologi, dan nilai-nilai ) yang digambarkan dalam novel Anak Rantau karya Ahmad Fuadi.

\section{METODE}

Dalam penelitian ini, metode yang digunakan adalah metode kualitatif. Metode penelitian kualitatif merupakan metode penelitian yang lebih menekankan pada aspek pemahaman secara mendalam terhadap suatu masalah daripada melihat permasalahan untuk penelitian generalisasi. Metode penelitian ini menggunakan teknik analisis mendalam (in-depth analysis), yaitu mengkaji masalah secara kasus per kasus karena metode kualitatif yakin bahwa sifat suatu masalah satu akan berbeda dengan sifat dari masalah lainnya.

Penerapan metode kualitatif ini bersifat deskriptif yang berarti data yang dihasilkan berupa berupa kata-kata dalam bentuk kutipan-kutipan (Arikunto, 2014: 6), metode kualitatif yang bersifat deskriptif yang dimaksud adalah bahwa data yang dikumpulkan berupa kata-kata, gambar, dan bukan angka-angka, sedangkan pendekatan yang dipakai adalah pendekatan sosiologi sastra dan pendekatan semiotika. 
Teknik pengumpulan data adalah cara yang dilakukan untuk mengumpulkan data yang diperlukan dalam penelitian. Pengumpulan data dilakukan dengan pembacaan novel Anak Rantau karya Ahmad Fuadi dan bukubuku yang membahas tentang sosio kultural masyarakat Minang secara cermat, terarah, dan teliti. Pada saat melakukan pembacaan tersebut, peneliti mencatat datadata tentang gambaran sosial masyarakat Minang dalam novel Anak Rantau karya Ahmad Fuadi yang berkenaan dengan ideologi dan nilai-nilai yang dihayati masyarakatnya.

\section{HASIL DAN PEMBAHASAN}

Novel Anak Rantau menceritakan tentang seorang perantau dari tanah Minang yang bernama Martiaz yang merasa gagal mendidik anaknya di tanah rantau yaitu Jakarta. Untuk menebus kegagalan itu, Martiaz berniat mengirim anaknya, Hepy, ke tanah minang, kampung halaman yang pernah ditinggalkannya karena ingin menentang adat.

Hepy yang semula sangat senang diajak pulang kampung oleh ayahnya, terpaksa harus menelan kekecewaan setelah tahu niat ayahnya yang sebenarnya. Dia merasa terbuang dan akhirnya harus menanggung dendam.

Persoalan semakin rumit karena Hepy harus berada dalam asuhan Datuk Marajo, kakeknya, yang sangat mengagung-agungkan adat Minang. Hepy harus belajar menyesuaikan adat yang sangat berbeda dengan tanah kelahirannya. Untunglah ada nenek Salisah dan Zen serta Attar, dua sahabat baru yang setia mendampinginya di masa-masa sulit. Petualangan Hepy bersama dua sahabatnya dan perjumpaannya dengan orang-orang kampung Tanjung Durian, terutama dengan Pandeka luko itulah yang membuat Hepy akhirnya terlepas dari beban dendam dan memahami ideologi orang Minang. Petualangan Hepy ternyata juga mampu memperbaiki adat yang mulai rusak akibat perubahan zaman dan mengembalikan ideologi yang sudah mulai pudar.

Dari hasil pembahasan mengenai aspek semantik novel Anak Rantau dapat disimpulkan, terdapat tiga kelompok masyarakat Minang yaitu, (1) kelompok masyarakat yang masih menetap di Minang, (2) kelompok masyarakat perantau, dan (3) kelompok muda atau masyarakat pendatang.

Secara umum cerita berisi usaha kelompok-kelompok masyarakat di Minangkabau yang mencoba memaknai ideologi dan nilai-nilai masyarakat Minang. Dimulai dari kegagalan kelompok masyarakat perantauan mendidik anaknya di perantauan. Kelompok yang pernah meninggalkan kampung halamannya untuk merantau itu menyadari bahwa ideologi yang ditanamkan adat kampungnya akan bisa memperbaiki kegagalannya di tanah rantau.

Berikutnya adalah usaha kelompok muda. Kelompok muda adalah kelompok yang tidak lahir di Minangkabau, tetapi dipaksa untuk tinggal dan menyesuaikan diri dengan adat Minangkabau karena orang tuanya merasa gagal mendidiknya di luar Minangkabau. Awalnya, kelompok ini tertekan dengan segala kebiasaan baru yang harus ia jalankan. Namun, lewat interaksinya dengan kelompok yang menetap, kelompok ini akhirnya justru mendapatkan hal-hal yang 
positif dan berguna bagi dirinya.

Sementara itu, di saat yang bersamaan, kelompok yang menetap mengalami keresahan karena berubahnya ideologi yang sudah dipakai sejak pendahulupendahulu mereka. Mereka berjuang keras untuk mengembalikan adat lampau agar tidak hilang dengan berbagai cara. Banyak tantangan yang mereka hadapi, termasuk dari kelompok perantau yang ternyata tidak semuanya baik. Kehadiran kelompok muda yang awalnya diremehkan, akhirnya sedikit-sedikit mampu memberi harapan baru untuk kembalinya adat yang mulai hilang. Dengan keberanian kelompok muda untuk menggagalkan beredarnya narkoba di Tanjung Durian, memompa semangat masyarakat yang lain untuk bersama-sama berjuang memperbaiki adat kampung.

Masing-masing kelompok masyarakat Minang memperlihatkan ideologi masing-masing. Namun, karena semua kelompok berasal dari darah yang sama yaitu darah orang Minangkabau, lewat berbagai peristiwa yang melanda tokohtokohnya, ketiga kelompok itu akhirnya mengakui ideologi yang sama yaitu alam takambang jadi guru, artinya, alam adalah guru terbaik untuk menimba pengalaman.

Pertemuan kelompok yang berbeda tentunya akan menciptakan benturan kepentingan antarkelompok. Awalnya mereka saling curiga satu sama lain. Namun, ketiga kelompok ini memilih untuk saling mengalah dan menerima. Akhirnya, terciptalah interaksi yang baik di antara ketiga kelompok tersebut.

Masyarakat Minang juga terimbas oleh perkembangan zaman. Masuknya teknologi turut mengubah pola pikir yang tradisional menjadi modern. Banyak anggota masyarakat yang mulai meninggalkan adat. Adat Minangkabau mulai berubah. Banyak yang pesimis adat kembali baik, namun ada pula yang tetap optimis bahwa adat Minangkabau akan tetap kuat. Munculnya semboyan membangkik akar terendam menguatkan tekad orang Minangkabau untuk membangun kembali adat Minangkabau yang sudah rusak.

\section{SIMPULAN}

Berdasarkan penelitian terhadap aspek sintaktik isi novel Anak Rantau karya Ahmad Fuadi ditemukan bahwa masalah dalam novel ini adalah usaha kelompokkelompok masyarakat yang ada di Minang untuk memaknai kembali adat istiadat Minangkabau yang telah hilang lewat peristiwa kegagalan kelompok perantau mendidik anaknya di tanah rantau, keterpaksaan kelompok muda yang harus menyesuaikan adat istiadat Minang, kegundahan kelompok yang menetap karena adat istiadat di kampungnya telah terkalahkan oleh teknologi.

Berdasarkan aspek semantik, digambarkan bahwa tokoh-tokoh cerita mewakili kelompok-kelompok masyarakat yang ada di Minangkabau, yaitu: kelompok masyarakat yang menetap di Minang, kelompok masyarakat yang merantau, dan kelompok muda. Mereka memiliki ideologi dan nilai-nilai yang berbeda sehingga memunculkan karakter yang berbeda-beda. Kelompok-kelompok ini saling berinteraksi sehingga menciptakan konflik. Namun, berkat interaksi antarkelompok ini konflik-konflik yang ada akhirnya dapat dipecahkan.

Berdasarkan isi cerita, disimpulkan bahwa, secara umum, cerita 
mengisahkan tentang kehidupan orang-orang Minangkabau dengan segala problematikannya.

Ada tiga kelompok masyarakat yang digambarkan dalam novel tersebut yaitu, (a) Masyarakat Minang yang bertahan di kampung, (b) Masyarakat perantau yang berasal dari tanah Minang, dan (c) masyarakat kota yang merantau di tanah Minang. Kelompok-kelompok masyarakat ini masing-masing diwakili oleh tokohtokoh yang menjadi anggota kelompok tersebut. Martiaz mewakili kelompok perantau, Datuk Marajo sebagai kelompok masyarakat Minang yang menetap di Minang, dan Hepi sebagai wakil darikelompok muda.

Masing-masing kelompok memperlihatkan ideologi masing-masing. Namun, karena semua kelompok berasal dari darah yang sama yaitu darah orang Minangkabau, lewat berbagai peristiwa yang melanda tokoh-tokohnya, ketiga kelompok itu akhirnya mengakui idiologi yang sama yaitu alam takambang jadi guru, artinya, alam adalah guru terbaik untuk menimba pengalaman.

Pertemuan kelompok yang berbeda tentunya akan menciptakan benturan kepentingan antarkelompok. Awalnya mereka saling curiga satu sama lain. Namun, ketiga kelompok ini memilih untuk saling mengalah dan menerima. Akhirnya, terciptalah interaksi yang baik di antara ketiga kelompok tersebut.

Masyarakat Minang juga terimbas oleh perkembangan zaman. Masuknya teknologi turut mengubah pola pikir yang tradisional menjadi modern. Banyak anggota masyarakat yang mulai meninggalkan adat. Adat Minangkabau mulai berubah. Banyak yang pesimis adat kembali baik, namun ada pula yang tetap optimis bahwa adat Minangkabau akan tetap kuat. Munculnya semboyan membangkik akar terendam menguatkan tekad orang Minangkabau untuk membangun kembali adat Minangkabau yang sudah rusak.

\section{DAFTAR PUSTAKA}

Arikunto, S. (2014). Prosedur Penelitian: Suatu Pendekatan Praktik. Jakarta: Rineka Cipta.

Damono, S. D. (1978). Sosiologi Sastra Sebuah Pengantar Ringkas. Jakarta: Pusat Pembinaan dan Pengembangan Bahasa.

Fuadi, A. (2017). Anak Rantau. Jakarta: Falcom Publishing.

Junus, U. (1986). Sosiologi Sastra Persoalan Teori dan Metode. Kuala Lumpur: Dewan Bahasa dan Pustaka.

Teng, H. M. B. A. (2017). Filsafat Kebudayaan dan Sastra (Dalam Perspektif Sejarah). Jurnal ilmu budaya, 5(1), 72-73.

Wellek, R., \& Warren, A. (1990). Teori Kesusasteraan. Jakarta:Gramedia. 